\title{
Front Matter: Volume 9937
}

, "Front Matter: Volume 9937," Proc. SPIE 9937, Next Generation Technologies for Solar Energy Conversion VII, $99370 Z$ (7 December 2016); doi: $10.1117 / 12.2262169$

SPIE Event: SPIE Optics + Photonics for Sustainable Energy, 2016, San Diego, California, United States 


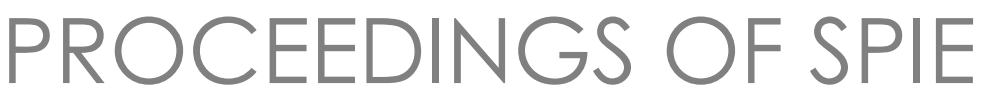

\title{
Next Generation Technologies for Solar Energy Conversion VII
}

\author{
Oleg V. Sulima \\ Gavin Conibeer \\ Editors
}

29-31 August 2016

San Diego, California, United States

Sponsored and Published by

SPIE 
The papers in this volume were part of the technical conference cited on the cover and title page. Papers were selected and subject to review by the editors and conference program committee. Some conference presentations may not be available for publication. Additional papers and presentation recordings may be available online in the SPIE Digital Library at SPIEDigitallibrary.org.

The papers reflect the work and thoughts of the authors and are published herein as submitted. The publisher is not responsible for the validity of the information or for any outcomes resulting from reliance thereon.

Please use the following format to cite material from these proceedings:

Author(s), "Title of Paper," in Next Generation Technologies for Solar Energy Conversion VII, edited by Oleg V. Sulima, Gavin Conibeer, Proceedings of SPIE Vol. 9937 (SPIE, Bellingham, WA, 2016) Sixdigit Article CID Number.

ISSN: 0277-786X

ISSN: 1996-786X (electronic)

ISBN: 9781510602656

ISBN: 9781510602663 (electronic)

Published by

SPIE

P.O. Box 10, Bellingham, Washington 98227-0010 USA

Telephone +1 3606763290 (Pacific Time) · Fax +1 3606471445

SPIE.org

Copyright @ 2016, Society of Photo-Optical Instrumentation Engineers.

Copying of material in this book for internal or personal use, or for the internal or personal use of specific clients, beyond the fair use provisions granted by the U.S. Copyright Law is authorized by SPIE subject to payment of copying fees. The Transactional Reporting Service base fee for this volume is $\$ 18.00$ per article (or portion thereof), which should be paid directly to the Copyright Clearance Center (CCC), 222 Rosewood Drive, Danvers, MA 01923. Payment may also be made electronically through CCC Online at copyright.com. Other copying for republication, resale, advertising or promotion, or any form of systematic or multiple reproduction of any material in this book is prohibited except with permission in writing from the publisher. The CCC fee code is 0277-786X/16/\$18.00.

Printed in the United States of America.

Publication of record for individual papers is online in the SPIE Digital Library.

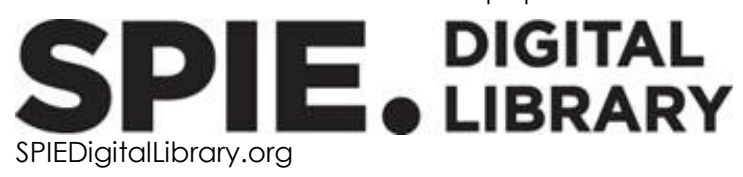

Paper Numbering: Proceedings of SPIE follow an e-First publication model. A unique citation identifier (CID) number is assigned to each article at the time of publication. Utilization of CIDs allows articles to be fully citable as soon as they are published online, and connects the same identifier to all online and print versions of the publication. SPIE uses a six-digit CID article numbering system structured as follows:

- The first four digits correspond to the SPIE volume number.

- The last two digits indicate publication order within the volume using a Base 36 numbering system employing both numerals and letters. These two-number sets start with $00,01,02,03,04,05$, $06,07,08,09,0 A, 0 B \ldots$. OZ, followed by 10-1Z, 20-2Z, etc. The CID Number appears on each page of the manuscript. 


\title{
Contents
}

\author{
$\checkmark$ Authors \\ vii Conference Committee
}

\section{NEW CONCEPTS AND APPROACHES I}

993703 Concentrating light in $\mathrm{Cu}(\mathrm{In}, \mathrm{Ga}) \mathrm{Se}_{2}$ solar cells [9937-1]

993704 Solar-thermophotovoltaic systems using spectrally selective absorber/emitter based on metal-dielectric multilayer [9937-2]

993705 High-efficiency solar energy conversion with spectrum splitting prismatic lens and multiple independent PV cells [9937-3]

993707 Metal hydrides as hot carrier solar cell absorber materials [9937-5]

QUANTUM DOTS, WIRES, AND WELLS

993708 Type II GaSb/GaAs quantum rings with extended photoresponse for efficient solar cells [9937-6]

993709 Evidence of suppressed hot carrier relaxation in type-II InAs/AIAs 1-x $_{\text {S }} \mathbf{b}_{\mathrm{x}}$ quantum wells [9937-7]

\section{PHOTON MANAGEMENT}

9937 OE Broadband-sensitive upconverters co-doped with $\mathrm{Er}^{3+}$ and $\mathrm{Ni}^{2+}$ for crystalline silicon solar cells [9937-12]

9937 OF Up-conversion equivalent circuit to boost current in Si cells [9937-13]

\section{NEW CONCEPTS AND APPROACHES II}

9937 OK Comparison of holographic lens and filter systems for lateral spectrum splitting [9937-19]

9937 OL Segmented holographic spectrum splitting concentrator [9937-20]

9937 OM Three junction holographic micro-scale PV system [9937-21]

9937 ON Environmental stability study of holographic solar spectrum splitting materials [9937-22]

993700 Concept of a methodical process for the design of concentrating photovoltaic systems according to the context of use [9937-23] 
9937 OP Tuning the colors of C-Si solar cells by exploiting plasmonic effects [9937-24]

\section{NEW CONCEPTS AND APPROACHES III}

9937 OR Measurement of photoluminescence from a twisted-nematic liquid crystal/dye cell for an application in an energy-harvesting display [9937-26]

9937 OS Performance assessment and transient optimization of multi-stage solid desiccant air conditioning systems with building PV/T integration [9937-27]

9937 ОT Energy storage capability of the dye sensitized solar cells via utilization of highly porous carbon electrodes [9937-28]

9937 OU Photoelectrochemical reaction in conducting polymers for solar energy harvesting and charge storage [9937-29]

9937 OV Selecting a proper design period for heliostat field layout optimization using Campo code [9937-30]

\section{POSTER SESSION}

9937 OX Enhancement of a-Si:H solar cell efficiency by $\mathrm{Y}_{2} \mathrm{O}_{3}: \mathrm{Yb}^{3+}, \mathrm{Er}^{3+}$ near infrared spectral upconverter [9937-34]

9937 OY Fluorescent simulation and experimental verification of luminescent solar concentrators [9937-36] 


\section{Authors}

Numbers in the index correspond to the last two digits of the six-digit citation identifier (CID) article numbering system used in Proceedings of SPIE. The first four digits reflect the volume number. Base 36 numbering is employed for the last two digits and indicates the order of articles within the volume. Numbers start with 00, 01, 02, 03, 04, 05, 06, 07, 08, 09, 0A, 0B...0Z, followed by 10-1Z, 20-2Z, etc.

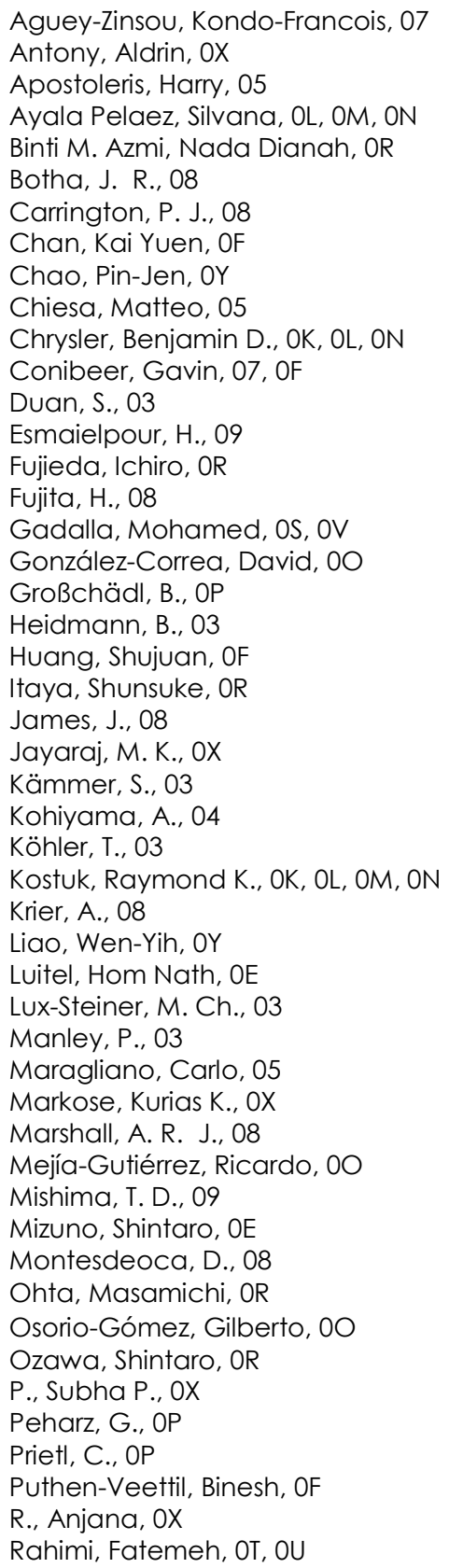

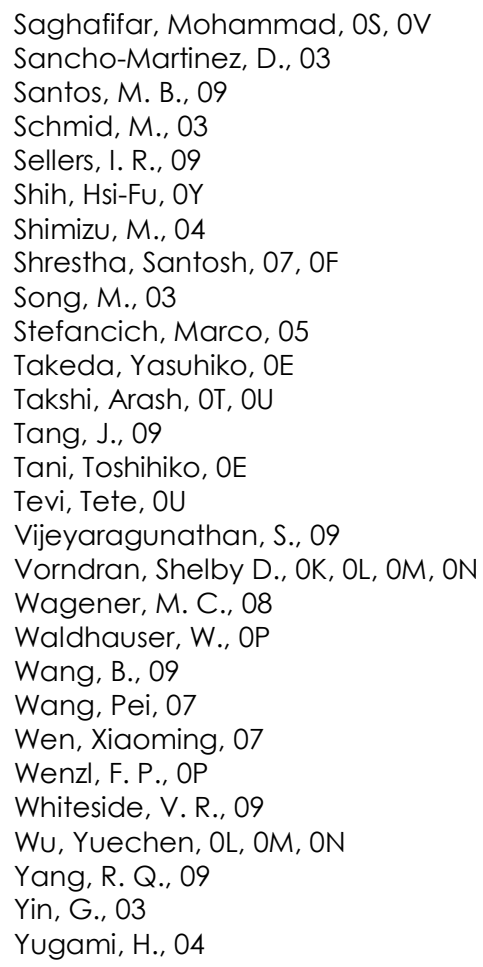


Proc. of SPIE Vol. 9937 99370Z-6

Downloaded From: https://www.spiedigitallibrary.org/conference-proceedings-of-spie on 26 Apr 2023 Terms of Use: https://www.spiedigitallibrary.org/terms-of-use 


\section{Conference Committee}

Symposium Chair

Oleg V. Sulima, GE Global Research (United States)

Conference Chairs

Oleg V. Sulima, GE Global Research (United States)

Gavin Conibeer, The University of New South Wales (Australia)

Conference Program Committee

Andrew J. Ferguson, National Renewable Energy Laboratory

(United States)

Alberto Salleo, Stanford University (United States)

Sean E. Shaheen, University of Colorado at Boulder (United States)

Wilfried G. J. H. M. van Sark, Utrecht Universiteit (Netherlands)

Xianfan Xu, Purdue University (United States)

\section{Session Chairs}

1 New Concepts and Approaches I

Oleg V. Sulima, GE Global Research (United States)

2 Quantum Dots, Wires, and Wells

Gavin Conibeer, The University of New South Wales (Australia)

3 Photon Management

Peter Bermel, Purdue University (United States)

4 New Designs and Concepts for Organic PV

Sean E. Shaheen, University of Colorado Boulder (United States)

5 New Concepts and Approaches II

Andru J. Prescod, SunShot Initiative, United States Deptartmrent of Energy (United States) and ManTech International Corporation (United States)

6 New Concepts and Approaches III

Andru J. Prescod, SunShot Initiative, United States Deptartment of Energy (United States) and ManTech International Corporation (United States) 
Proc. of SPIE Vol. 9937 99370Z-8

Downloaded From: https://www.spiedigitallibrary.org/conference-proceedings-of-spie on 26 Apr 2023 Terms of Use: https://www.spiedigitallibrary.org/terms-of-use 